\title{
ArTe E NATUREZA: SOBRE A VIAGEM DE GOETHE À ITÁLIA
}

\author{
Pedro Süssekind
}

Resumo: O ensaio a seguir tematiza o livro Viagem à Itália, no qual J. W. Goethe relata o período passado em território italiano, nos anos de 1786 e 1787. Procuro contextualizar essa viagem na vida e na carreira do escritor, servindo-me, para isso, especialmente de um texto sobre ele escrito por Walter Benjamin. Comento as observaçôes de Goethe sobre a natureza, ligadas a suas pesquisas científicas, mas meu principal interesse são as observaçôes sobre a arte e sobre a Antiguidade. Nestas, identifico não só a importante influência do historiador da arte J. J. Winckelmann, como também a orientação para o classicismo, algo que marcaria a produção artística de Goethe a partir daquele período passado em território italiano.

Palavras-ChavE: Goethe. Winckelmann. Arte. Natureza. Classicismo.

1.

No dia 27 de outubro de 1786, Goethe visitava Terni, uma pequena cidade entre dois rios, cercada pela bela paisagem da regiáo central da Itália e cheia de vestígios do mundo antigo, como as ruínas de Carsula, o piso bem conservado da Via Flaminia, os templos de Castor e Pólux e o aqueduto que liga uma montanha a outra. Ao anoitecer, ele registrou em seu diário de viagem as impressóes a respeito do que tinha encontrado ali, comentando como a presença real das coisas observadas contrastava com as dificuldades do "esforço por adquirir uma ideia da Antiguidade" (GOETHE, 1999, p. 143). Se normalmente esse esforço era marcado pela "sensação decorrente de nos depararmos apenas com ruínas a partir das quais temos de reconstruir de forma precária aquilo de que ainda não temos ideia”, o solo clássico revelava para o escritor um novo modo de apreensão, menos fantasioso e sentimental. Goethe

\footnotetext{
${ }_{1}$ Professor Associado do Departamento de Filosofia da Universidade Federal Fluminense (UFF), Niterói, RJ - Brasil. (D) https://orcid.org/0000-0001-5545-6855. E-mail: pedrosuss@gmail.com Bolsista de produtividade em pesquisa do CNPq.
}

http://dx.doi.org/10.1590/0101-3173.2019.v42n3.05.p73 
fala em apreender a região "em sua realidade, conforme ela se apresenta", ou em se valer "da contemplação da geologia e da paisagem no sentido de reprimir a fantasia e os sentimentos, com o intuito de adquirir uma visão límpida e clara dos lugares". Só assim se perceberia que a regiáo continuava a ser "o mesmo palco decisivo no qual se desenrolaram os grandes feitos do passado", de modo que aquele esforço abstrato de imaginar a Antiguidade daria lugar a uma nova conexão com o passado, na qual a história, "de forma maravilhosa e vívida", "sem que compreendamos como isso ocorre", vinha a se juntar aos lugares contemplados.

O contraste entre a observação cuidadosa e a fantasia sentimental é um tema recorrente nas anotaçôes feitas pelo escritor, durante aquela viagem, nas quais o interesse e a pesquisa sobre o mundo antigo aparecem atrelados aos lugares visitados a cada dia. Márcio Seligmann-Silva comenta, em ensaio sobre Goethe e seu precursor Winckelmann:

O trabalho de revitalizar o mundo antigo através de suas obras, Goethe levou a cabo também nas suas descriçóes do mundo romano antigo a partir de sua observação do mundo italiano moderno. Na Viagem à Itália com frequência o leitor é assaltado por dois recursos narrativos de revitalização característicos: Goethe introduz no meio da narração cenas da Antiguidade produzidas por sua imaginação ou simplesmente lê na paisagem geográfica natural e cultural dados que recordam aquele mundo parcialmente soterrado. (SELIGMANN-SILVA, 2005, p. 262).

Roma, a próxima etapa depois da passagem por Terni, constituía o principal objetivo daquela viagem, iniciada quase dois meses antes e desejada desde a infância. Numa das primeiras notas registradas na capital italiana, no dia $1^{\circ}$ de novembro de 1786 , Goethe conta que, quando era criança, havia gravuras em cobre, penduradas por seu pai na casa da família em Frankfurt, com cenas que ele agora via de verdade, junto com as imagens de todos os outros desenhos e representaçôes da Itália que ele tinha aprendido a admirar depois e que alimentavam os sonhos da sua juventude. Ele faz dois comentários a respeito dessa descoberta real dos locais antes imaginados: "Pode-se dizer que uma nova vida tem início quando se vê com os próprios olhos aquilo que em parte se conhece tão bem, por dentro e por fora" e, em seguida, "aonde quer que eu vá, encontro velhos conhecidos num novo mundo; tudo é como eu imaginava, e tudo é novo." (GOETHE, 1999, p. 149). 
Uma vez que o relato da Viagem à Itália só foi publicado tardiamente (a primeira e a segunda parte em 1816, a última em 1829), e as anotaçóes originais foram elaboradas durante muitos anos para chegar à versão final, certamente houve um esforço de dar, aos fatos contados, o sentido que eles deveriam ter na vida e na carreira do autor. Como nas suas memórias, ou em alguns trechos autobiográficos presentes nas obras de ficção, Goethe procura estabelecer ressonâncias entre o conteúdo objetivo dos acontecimentos e o desenvolvimento de suas experiências pessoais ou o percurso de sua formaçáo intelectual. Uma indicação disso é o que ele escreveu em Roma, em 20 de dezembro de 1786: "O renascimento que me transforma de dentro para fora segue seu curso. Por certo, eu acreditava que fosse aprender de verdade aqui; mas não pensei que fosse ter de voltar à escola primária, que precisaria desaprender, ou verdadeiramente reaprender tanto." (GOETHE, 1999, p. 178). O aprendizado, a partir da observação dos lugares visitados na Itália do século XVIII, diz respeito ao contato e à relaçáo com a Antiguidade, numa espécie de renascimento íntimo.

\section{2.}

Em seu artigo enciclopédico sobre Goethe, Walter Benjamin chama a atenção para o fato de que o escritor teve, durante a vida inteira, certa resistência em relação aos grandes centros urbanos (BENJAMIN, 2009, p. 123). Depois que partiu definitivamente de Frankfurt, sua cidade natal, só a visitou duas vezes, mesmo assim de passagem, e nunca pôs os pés em Berlim. Goethe passou a maior parte de sua vida na pequena Weimar, que, na época, tinha aproximadamente 6.000 habitantes. As exceçôes a essa preferência foram justamente as visitas a Roma e Nápoles, durante a longa permanência na Itália, de 1786 a 1788.

Embora esse fato possa estar ligado a traços da personalidade do escritor, ele é indicativo também da situação política da Alemanha, na segunda metade do século XVIII. Segundo as informaçōes fornecidas por Benjamin, a cidade de Frankfurt tinha apenas 30.000 habitantes, em 1749, ano do nascimento de Goethe, e Berlim, a maior cidade do império alemão, contava com 126.000, quando Paris e Londres já haviam ultrapassado os 500.000 habitantes cada uma (BENJAMIN, 2009, p. 123). Como a revolução burguesa na Europa dependeu em larga escala das grandes cidades, os números demons- 
tram o atraso no desenvolvimento da burguesia alemã, da qual Goethe foi um dos maiores expoentes artísticos.

Economicamente, a situação da Alemanha naquele período se caracterizou pelo declínio das cidades mais poderosas, que vinham perdendo sua importância comercial para os centros holandeses e ingleses, desde o século XVI, quando começaram as grandes navegaçôes e o comércio marítimo no Oceano Atlântico. Essa situação era também o resultado de um longo período de guerras e conflitos, no qual o Sacro Império Romano-Germânico enfrentou a Reforma luterana e as revoltas camponesas. $\mathrm{O}$ ápice dessas revoltas, a Guerra dos Camponeses ocorrida de 1524 a 1526, forneceu a Goethe, aliás, o argumento para sua primeira peça, Götz von Berlichingen. A ideologia que motivava os camponeses nas revoltas era uma expressáo social da contestação religiosa de Lutero à autoridade do Império e da Igreja Católica. Um século depois, a Guerra dos 30 Anos, que se estendeu de 1618 a 1648, causou o colapso do comércio alemão. E, ao final da guerra, a soberania dos príncipes territoriais alemães foi consolidada, mantendo-se sem controle político central até a unificação de 1870. Considerando essas características, não era de se estranhar que as grandes cidades alemãs tivessem, no ano de nascimento de Goethe, uma população muito menor do que a de Paris ou Londres, na mesma medida em que Weimar e várias outras pequenas cortes prosperavam (ELIAS, 1993, p. 91-97).

Iniciado em torno de 1770, o Sturm und Drang (tempestade e ímpeto) - movimento pré-romântico de que Goethe tomaria parte - buscava um caminho ideológico novo na Alemanha (BENJAMIN, 2009, p. 125). Contudo, já que esse caminho estava ligado à emancipaçáo burguesa, o movimento enfrentava um problema do ponto de vista social, nessa época em que a burguesia alemã, de formação atrasada, não tinha a mesma importância política alcançada na França ou na Inglaterra (HAUSER, 2000, p. 598-600). Uma das consequências dessa situação era que os artistas e intelectuais, embora defendessem as ideias novas, não podiam trabalhar sem o auxílio dos nobres, nas várias cortes em que o país era dividido.

Nesse contexto, Goethe surgiu como expoente do Sturm und Drang e foi apontado por Herder, um dos mentores desse movimento, como um autêntico gênio nacional (HERDER, 1984, p. 527). ${ }^{2}$ Segundo a interpretação

\footnotetext{
${ }^{2}$ Num ensaio de 1773, em que propunha Shakespeare como modelo para o teatro de seu país, Herder já identificara Goethe como um gênio alemão à altura desse modelo. $\mathrm{O}$ autor se dirige pessoalmente ao jovem escritor que conhecera em Estrasburgo, poucos anos antes: "Você, meu amigo, que se reconhece nesta leitura, [...] ainda pode ter seu sonho doce, digno, de produzir sua homenagem a ele
} 
de Benjamin, a primeira obra lançada pelo escritor, a já mencionada peça Götz von Berlichingen, de 1772, expressava as divisóes da burguesia alemá naquela época: as cidades e as cortes representam o racionalismo sem espírito, enquanto o líder da revolta dos camponeses, o cavaleiro que dá nome à peça, personifica os princípios do Sturm und Drang na tenacidade de sua rebeldia (BENJAMIN, 2009, p. 128).

O Sturm und Drang se desenvolveu sobretudo no campo do teatro, com as peças que construíram a base para o surgimento de uma dramaturgia nacional alemã, contestando a influência e a autoridade do classicismo francês, cujo modelo dominou a cena cultural da primeira metade do século XVIII. O Götz von Berlichingen não segue esse modelo da dramaturgia de Corneille e de Racine, e sim a influência dos dramas históricos shakespearianos. Por isso mesmo, num texto de louvor a Shakespeare escrito em 1771, quando trabalhava em sua primeira peça, Goethe afirma: "Quanto ao teatro grego, que os franceses tomavam como modelo, segundo suas qualidades internas e externas, era mais fácil que um marquês pudesse imitar Alcibíades do que seria possível a Corneille seguir Sófocles." (GOETHE, 2000, p. 27). Muitos anos depois, em suas memórias, ao falar das tendências seguidas por sua geração na juventude, ele faria um balanço daquele momento inicial do Sturm und Drang e da contestaçáo do modelo cultural que imperava até entáo:

Fomos de repente libertados e desembaraçados do espírito francês. A maneira de viver dos nossos vizinhos nos parecia excessivamente imobilizada e aristocrática; sua poesia era fria, sua crítica negativa, sua filosofia abstrusa e contudo insuficiente; de modo que estávamos a ponto de nos abandonar [...] à natureza inculta, se uma outra influência não nos tivesse há muito tempo preparado para concepçóes filosóficas e prazeres intelectuais mais elevados, mais livres. (GOETHE, 1986, p. 377).

A segunda obra publicada por Goethe foi o romance epistolar $O s$ sofrimentos do jovem Werther, de 1774, um sucesso sem precedentes na literatura alemã. Em pouco tempo, passou a ser o livro mais lido no país, depois da Bíblia, e as pequenas localidades em que a história acontece, Wetzlar e Garbenheim, viraram locais de peregrinação. Traduzido para outras línguas, o Werther ultrapassou as fronteiras nacionais e tornou o seu autor famoso em toda a Europa. Ainda de acordo com Benjamin, nesse livro, Goethe faz de seu

[Shakespeare] a partir da nossa época de cavaleiros, em nossa língua." Depois de afirmar que inveja o sonho de Goethe, ele aconselha: "Não arrefeça sua nobre atividade alemã até que ela seja coroada." 
mundo interior um assunto público e, das questóes de sua época, questóes de seu mundo particular de experiências (BENJAMIN, 2009, p. 128). Por isso, a burguesia alemã encontraria, nesse romance, a expressão plena das suas principais reivindicaçôes: a valorização do indivíduo livre e a luta contra as convençóes tradicionalmente estabelecidas.

\section{3.}

Na volta de uma viagem para a Suíça, pouco tempo depois da publicação do Werther, Goethe conheceu o príncipe herdeiro e futuro duque Karl August von Sachsen-Weimar-Eisenach, num encontro que mudaria sua vida. Em novembro de 1775 , o escritor aceitou o convite do nobre para visitar a corte de Weimar, que acabou se tornando sua morada, desde aquela época, por mais de cinquenta anos. Goethe teve uma participação intensa na vida política e social da corte, como alto funcionário do governo, conselheiro secreto, diretor da companhia de teatro e, durante algum tempo, ministro de Estado. Em suas próprias palavras, já velho, nas conversas registradas por Eckermann [(19--?), p. 11]:

Onde se encontrará, numa região tão pequena, tanto de notável? Temos também uma biblioteca escolhida e um teatro que não fica atrás, nas coisas fundamentais, dos melhores das outras cidades alemâs. Insisto portanto: fique conosco, e não só por este inverno, escolha Weimar para residência. Partem de lá os caminhos para todos os extremos do mundo. No verão, viaje e veja a pouco e pouco aquilo que deseja observar. Eu há cinqüenta anos que lá vivo, e em quantos sítios não tenho estado! - mas volto sempre com prazer.

No mesmo ano de sua chegada à corte, o escritor foi nomeado pelo jovem duque Conselheiro de Legação, com uma série de incumbências administrativas, como a inspeção das estradas, a seleção de jovens para o serviço militar e decisôes relativas ao planejamento urbano e à agricultura. Apesar do acúmulo dessas atividades práticas, Goethe ainda conciliava as incumbências administrativas e a produção poética com seu grande interesse pelas ciências naturais, que mais tarde o levaria a escrever tratados de botânica, ótica, mineralogia e meteorologia. Ao comentar o rumo de seus estudos naturalistas, num texto intitulado "História de meus estudos de botânica", ele afirma que a curiosidade por essa esfera das ciências se desenvolveu exatamente na época em que foi acolhido pelo círculo weimariano (GOETHE, 1975, p. 81-83). Assim, enquanto seu período de formação juvenil, nas cidades de Frankfurt, Leipzig e Estrasburgo, alimentara o interesse pela vida social e a inclinação para as letras, a vida no campo, com incursóes de caça ou inspeção, voltou sua atenção para a observação da natureza. 
Os musgos da floresta da Turíngia tinham sido seus primeiros objetos de estudo, por volta de 1777, numa pesquisa que o levou a ler os tratados de botânica mais recentes e a redigir suas próprias notas. Segundo o relato do autor, esse primeiro passo como naturalista levou a seu crescente entusiasmo pelas pesquisas das formaçôes geológicas, pela classificação dos minerais e pelo estudo das condições climáticas (GOETHE, 1975, p. 82).

Para Benjamin, em sua análise da posição política de Goethe, a dedicação às ciências naturais, substituindo os temas sociais de sua produção poética anterior, poderia ser encarada como uma espécie de isolamento dos problemas debatidos nas cidades (BENJAMIN, 2009, p. 154). Nesse caso, também fica indicado o afastamento da ideologia do movimento pré-romântico, num processo do qual a relação com o duque de Weimar e a aceitaçáo do cargo de conselheiro da corte são os primeiros indícios. Para a decepção de muitos dos seus contemporâneos, o autor do Götz e do Werther abandonava, assim, a defesa de posiçôes contra as convenções aristocráticas. E a inserção definitiva de Goethe na sociedade weimariana, estabelecida formalmente com o título de nobreza recebido em 1782, pode indicar a conclusão desse processo.

Mas a estabilidade da situação de Goethe em Weimar não impediu o desenvolvimento do que Benjamin chama, talvez exageradamente, de uma "contrariedade patológica com a Alemanha", uma certa resistência, "proveniente do mais íntimo de seu ser, contra o clima e a paisagem, contra a história, a política e o caráter do povo." (BENJAMIN, 2009, p. 138). Nessa tendência, revela-se a diferença em relação ao ideal de Herder, que via em Goethe o grande gênio alemão autêntico, e a proximidade com Winckelmann, o estudioso da Antiguidade Clássica que foi incapaz de voltar de Roma a seu país natal (GOETHE, 1965, p. 275). ${ }^{3}$

4.

A partida para a Itália, em 1786, foi descrita por Goethe como uma espécie de "fuga", da qual apenas o duque foi avisado, para viabilizar um pla-

\footnotetext{
3 Goethe conta a história num texto sobre Winckelmann: em 1768, ele tinha a intenção de voltar à Alemanha para uma visita breve, após longo período de permanência na Itália, mas desistiu no meio da viagem, em função da melancolia que sentiu, ao contemplar a paisagem de seu país natal. A Alemanha parecia triste ao autor apaixonado pelas cidades italianas. No entanto, a decisão de retornar o quanto antes a Roma acabou se revelando uma fatalidade, pois foi em Trieste, durante a viagem de volta, que Winckelmann foi assassinado a golpes de punhal por um homem que acabara de conhecer (cf. o artigo “A Grécia de Winckelmann." Kriterion, v. 49, n. 117, p. 67-77, 2008.)
} 
no alimentado desde a infância, mas quase inviável naquele momento em que suas funçóes administrativas e seu círculo social o prendiam à corte. $\mathrm{O}$ descontentamento do escritor com a Alemanha e a profunda identificação com o clima e o ambiente italianos se manifestam, em gradação crescente, nas descriçôes feitas durante as primeiras etapas do relato de viagem. No Tirol, ao se aproximar da fronteira com a Itália, Goethe declara que, "subindo adiante, para além de Innsbruck, a beleza é cada vez maior, e não há como descrevê-la." (GOETHE, 1999, p. 19). No entanto, ele a descreve minuciosamente, seja com um olhar de pintor de paisagens, destacando o esplendor das montanhas, seja sob a ótica de um naturalista que teoriza a respeito da formação geológica, do clima e da vegetação.

Numa das descriçôes pictóricas da primeira etapa da viagem, na regiáo de Brenner, em 8 de setembro de 1786, o autor assume uma posição "entre o Sul e o Norte", entre o destino da viagem, a Itália, e o ponto de partida, a Alemanha, como que para estabelecer uma ligação íntima e expressiva do ambiente em torno com a experiência pessoal de viajante:

Pouco a pouco, foi escurecendo cada vez mais; os detalhes perdiam-se e as massas foram se fazendo cada vez maiores e mais magníficas; por fim, quando tudo à minha frente já se movia feito uma pintura profunda e misteriosa, tornei a ver, de súbito, lá no alto, os cumes nevados iluminados pela lua; aguardo agora que a manhá venha clarear este precipício de pedra, esta linha divisória entre o Sul e o Norte na qual me encontro fincado. (GOETHE, 1999, p. 20).

Há também, no relato dessa mesma etapa, no Tirol, vários exemplos da importância que Goethe dava à observação dos fenômenos naturais, voltada para diversos ramos da ciência. No dia 8 de setembro de 1786, ele descreve as características dos Alpes calcários, identificando os tipos de rocha de cada trecho, e conta ter recolhido amostras, como faria depois, em todas as regióes percorridas, para enviar a Weimar as coleçóes cuidadosamente catalogadas. Os comentários da variação rochosa encontrada perto de Brenner são dignos de um mineralogista experiente: "Recostada em micaxisto de um verde e um cinza escuros e perpassada de quartzo, vi uma rocha calcária branca e compacta, exibindo a mica em sua degradação e aflorando em massas enormes." (GOETHE, 1999, p. 20).

Em sua longa consideração sobre o clima, Goethe desenvolve ainda o que chama de "estranhas teorias" de um "meteorologista ambulante", nas quais 
atribui as alteraçóes atmosféricas a uma atuação velada e secreta das montanhas, em função da força de atração exercida pela massa terrestre em suas grandes elevações (1999, p. 22). Ele acrescenta, além disso, "algumas palavras sobre o reino vegetal”, algo que constituiria um de seus temas científicos prediletos, durante todo o relato da viagem, porque essas observaçóes se inseriam no projeto de escrever uma obra a respeito da origem morfológica das plantas. Há diversos comentários sobre as árvores encontradas ao longo do caminho, como um ácer identificado para a filha de um harpista, ou os primeiros lariços, subindo para Brenner, e o primeiro zimbro, perto de Schönberg. Mais adiante, os novos tipos vegetais observados em território italiano reforçariam a teoria exposta em $A$ metamorfose das plantas, de 1790, como registrou o autor em Palermo, no dia 17 de abril de 1787:

As muitas plantas que eu, em geral, só estava acostumado a ver em cubas e vasos, por trás de vidraças a maior parte do ano, encontram-se aqui felizes e viçosas ao ar livre e, cumprindo seu destino em sua plenitude, fazem-se mais compreensíveis a nós. À visão de tantas formas novas e renovadas, voltou-me à mente a velha fantasia de poder, talvez, descobrir aqui, em meio a toda essa variedade, a planta primordial. (GOETHE, 1999, p. 314).

Para completar o escopo das observaçôes científicas do escritor, a aparência e os costumes das pessoas que ele encontra em cada localidade também são investigados. No decorrer da viagem, tanto os campos quanto as cidades da Itália suscitam consideraçôes que tratam não só das características físicas, mas também dos hábitos diversos, analisados em seu contexto como resultados das condiçóes naturais e culturais. Em Nápoles, por exemplo, nas anotaçóes de 28 de maio de 1787, Goethe chega a desenvolver um pequeno estudo das atividades dos cidadãos, a fim de mostrar como era descabida a crítica de muitos europeus do norte que se queixavam do grande número de desocupados (GOETHE, 1999, p. 390). E já no início de sua estada em território italiano, ao descer de Brenner, o escritor observava uma "mudança desagradável nas feiçóes e na cor da pele", especialmente no caso das mulheres, e atribuía essa mudança à dieta dos habitantes, cuja base era a polenta. As perguntas sobre o assunto a moradores da região e as observaçóes dos diferentes tipos humanos serviram de base para uma comparaçáo entre os costumes do tirolês alemão e do italiano, na qual as características físicas são associadas aos hábitos alimentares e às atividades de homens e mulheres, em cada localidade (GOETHE, 1999, p. 45-46). 
A "fuga" de Weimar para realizar aquele plano idealizado havia tantos anos ganha no relato Viagem à Itália, aos poucos, o significado de uma libertação pessoal. Um dos trechos mais expressivos é o de 11 de setembro de 1786, quando o autor tinha atravessado a fronteira e, pela primeira vez, entrara no território italiano:

E agora, ao anoitecer, com o vento suave e as montanhas rodeadas por poucas nuvens, mais fixas do que atravessando o céu, o zumbido agudo das cigarras começando a se fazer ouvir logo após o pôr-do-sol, sentimonos afinal em casa no mundo, e não qual estivéssemos escondidos ou no exílio. Desfruto de tudo isso como se tivesse nascido e sido criado aqui, e retornasse agora de uma caça à baleia na Groenlândia. Saúdo até mesmo a poeira desta terra. (GOETHE, 1999, p. 31).

O fato de Goethe sentir-se finalmente "em casa no mundo" é reforçado pela curiosa inversão entre sua verdadeira condição, como estrangeiro que visita um local novo, e a sensação exultante em que se expressa o ideal nostálgico do Sul, ligado ao encantamento pela natureza e ao interesse artístico. É como estudante de pintura, discípulo de Adam Friedrich Oeser, de quem fora aluno em Leipzig, que o autor desfruta da bela paisagem; e é como um autêntico seguidor de Johann Joachim Winckelmann que ele saúda até a poeira do território italiano, na qual encontrará os vestígios da Antiguidade. No entanto, só por meio de uma identificação mais profunda de seu espírito, um alemão pode dizer, ao realizar o plano alimentado desde a infância de conhecer um país estrangeiro, que a sensação é de não estar mais "escondido" ou no "exílio", como se retornasse de uma longa viagem a um território inóspito para o acolhimento de sua "casa". Ele indica, com isso, o sentimento contraditório que o acompanhava antes da viagem e que Benjamin identificou como sendo aquele "descontentamento patológico" com a Alemanha. Ou seja, considerando-se em casa quando chegava ao território estrangeiro e, diante desse sentimento, referindo-se ao passado em seu próprio país como um exílio, o escritor ressalta não só o seu amor winckelmanniano pela beleza da Itália, mas também a sua necessidade de tomar distância do ambiente e da cultura alemães. Desse modo, é como se o itinerário da viagem e o caminho de aprendizado pessoal, ou de formação espiritual, estivessem em harmonia e aparecessem no relato da viagem com a naturalidade de um movimento preciso, pleno de sentido. 


\section{5.}

Apesar da intensa dedicação às observaçôes da natureza, o caminho do aprendizado de Goethe na Itália só pode ser entendido, em sua plenitude, a partir das consideraçôes relativas às cidades italianas, como Verona, Veneza e Roma. Há uma mudança no foco da atenção do escritor, quando ele chega, depois de atravessar os Alpes, aos primeiros centros urbanos percorridos em sua jornada. Embora mantenha aquele interesse pelas ciências naturais, especialmente pela botânica, o principal tema do relato passa a ser a arte.

O pintor de paisagens que se expressa nas descriçôes dos Alpes dá lugar ao estudioso de pintura que, em Veneza, estuda os grandes mestres Ticiano e Veronese. Depois de ver os quadros que têm cenas venezianas como tema, a própria cidade parece oferecer ao observador uma explicação a respeito da luminosidade dessas pinturas. Goethe se refere ao seu "velho dom de ver o mundo com os olhos do pintor cujos quadros acabei de contemplar", capacidade que suscita a noção de que "os olhos se formam em consonância com os objetos que divisaram desde a infância, e, sendo assim, o pintor veneziano há de ver tudo com maior clareza e limpidez do que os outros homens." Ele descreve o aprendizado a respeito desse olhar, no qual as informaçóes visuais do lugar se revelam como uma base para a compreensão da arte ali desenvolvida:

Passeando pelas lagunas com o sol a pino, a contemplar os gondoleiros postados nas bordas de suas gôndolas, pairando com leveza em suas roupas coloridas e a remar, vendo-os, pois, desenharem-se no céu azul sobre a superfície clara da água, vi, na realidade, a melhor e mais fresca pintura da escola veneziana. O brilho do sol destacava de maneira ofuscante as cores locais, e as sombras eram tấo luminosas que, comparativamente, teriam podido fazer as vezes de luzes. A mesma coisa se podia dizer dos reflexos da água do mar. Tudo isso numa pintura sobrepondo o claro ao claro, de tal modo que, para pôr os pingos nos is, foram necessárias a onda espumante e a luz radiante a iluminá-la. (GOETHE, 1999, p. 102).

Em sua descrição de Veneza com olhos de Veronese e Ticiano, Goethe dá mostras de sua relação com a escola de Oeser e Winckelmann, autores para os quais a interpretação das obras de arte deve ser baseada na investigação das condiçôes específicas de seu surgimento. E essa filiação é ressaltada especialmente depois, em Roma, onde o escritor se dedicou à observação das obras da Antiguidade clássica. 
Em alguns momentos, Goethe se refere de modo direto a Winckelmann, cujos passos seguia, na capital italiana, lendo cartas do historiador enviadas daquela cidade para amigos alemães. Por exemplo, no dia 13 de dezembro de 1786, ao citar o trecho de uma carta de Winckelmann que fala de Roma como "a escola suprema para o mundo todo", um lugar que depura e testa o viajante, Goethe considera que o pensamento se "aplica bem" ao seu modo de observar as obras de arte e aprender com elas. Em seguida, ele conclui: "Com certeza, não se tem, se não se está em Roma, a menor ideia de como se é nela escolado. É preciso renascer, e então as ideias anteriores serão vistas como sapatinhos de criança." (GOETHE, 1999, p. 177). No mesmo dia, animado com essas conclusôes a respeito de sua formação, ele avaliaria aquele ano como o mais importante de sua vida.

Já em 28 de janeiro de 1787, estão registradas duas consideraçóes que permeiam todas as coisas observadas em Roma, e ambas remetem também a Winckelmann, com quem Goethe conta ter aprendido a "separar as épocas, a reconhecer o estilo sempre diverso de que os povos se serviram." (GOETHE, 1999, p. 198). A primeira consideração, ligada diretamente a esse aprendizado, é a de que, "diante da gigantesca, embora fragmentária riqueza desta cidade, diante de cada objeto de arte, perguntamos pelo tempo que o produziu." A segunda consideração é quase um comentário da maneira como Winckelmann investigava as esculturas, a partir dos procedimentos específicos dos artistas que, na Grécia antiga, observavam nos ginásios os corpos humanos em movimento e, assim, foram capazes de formar um conceito mais geral do belo como um ideal de perfeição ligado ao divino (SÜSSEKIND, 2008, p. 67-77). Seguindo seu precursor, Goethe (1999, p. 199) fala em "investigar de que modo procediam aqueles incomparáveis artistas no desenvolvimento, a partir da figura humana, de seu círculo perfeitamente acabado de figuras divinas, no qual não falta um único traço essencial."

Nas teorias apresentadas por Winckelmann, em suas Reflexóes sobre a imitação das obras gregas na pintura e na escultura, de 1755, o belo ideal e a imitação dos antigos são as duas noçóes fundamentais que articulam o estudo do mundo clássico. O historiador da arte define assim no que consiste essa beleza ideal: "Enfim, o traço geral preponderante das obras-primas gregas é uma nobre simplicidade e uma calma grandeza, tanto na postura quanto na expressão." (WINCKELMANN, 1990, p. 142). A nobre simplicidade, associada à contenção da escultura antiga, se contrapóe ao rebuscamento da arte barroca, da qual Winckelmann era um crítico. Já a calma grandeza diz respeito 
a uma serenidade mais profunda, que se descobre sob a superfície, como que por trás do posicionamento do corpo e da expressão do rosto. A grandiosidade da arte antiga estaria ligada, portanto, às manifestaçóes da nobreza e da serenidade da alma na simplicidade das formas do corpo e do rosto, ou no contraste entre a tensão corporal e a expressão facial. Winckelmann usa uma metáfora para ilustrar essa definição: "Assim como a profundeza do mar permanece tranquila, por mais tempestuosa que esteja a superfície, a expressão nas figuras dos gregos mostra, em meio a todas as paixóes, uma alma grande e comedida." (WINCKELMANN, 1990, p. 142). E Goethe parece se referir exatamente a esse trecho, quando recorre à mesma metáfora do mar, para descrever sua estada em Roma, numa anotação do dia 25 de janeiro de 1787:

Torna-se para mim, agora, cada vez mais difícil prestar contas de minha estada em Roma; assim como o mar se faz cada vez mais profundo quanto mais o adentramos, assim acontece comigo na contemplação desta cidade. [...]. Não se pode conhecer o presente sem o auxílio do passado, e a comparação de ambos demanda maior tempo e tranquilidade. (GOETHE, 1999, p. 197).

\section{6.}

Para indicar a influência direta desse aprendizado winckelmanniano na obra de Goethe, basta lembrar que a versão definitiva da sua peça Ifigênia em Táuris foi escrita na Itália, durante o período de intensas observações da arquitetura e da escultura a que ele alude, em seu relato de viagem. Justamente essa peça, um dos melhores exemplos do classicismo de Goethe, motivou posteriormente a avaliaçáo feita por Schiller, numa das primeiras cartas da longa correspondência entre os dois escritores. Escrita em 23 de agosto de 1794, a carta descreve o curso do espírito de Goethe:

Como nasceu alemão, como seu espírito grego foi lançado na criação nórdica, só lhe restou uma alternativa: ou tornar-se um artista do norte ou dar à sua imaginação, com o auxílio da força do pensamento, aquilo de que a realidade a privou e assim engendrar uma Grécia, por assim dizer a partir do interior e por uma via racional. (GOETHE; SCHILLER, 1993, p. 24).

O que Schiller define como a capacidade artística de engendrar uma Grécia por uma via racional concerne à maneira como Goethe retomou e reelaborou o mito de Ifigênia, a filha que o rei Agamenon deveria sacrificar, para aplacar os deuses e permitir a partida das naus gregas para guerrear em Troia 
(SÜSSEKIND, 2007). A parte inicial da versão de Goethe segue os passos do original grego, com a elaboração de dois enredos em paralelo, para chegar ao reencontro dos irmãos. Mas o final da peça diverge do enredo contado por Eurípides. Na versão grega, há um plano de fuga bem-sucedido, para o qual Ifigênia precisa enganar o rei dos citas, com o argumento de que era necessário lavar a estátua da deusa, maculada pela presença de um assassino, antes de realizar o sacrifício do prisioneiro. Já no ato final da peça de Goethe, a protagonista desiste de seguir o plano, porque náo seria capaz de mentir. Em "Sobre o classicismo da Ifigênia de Goethe", Adorno comenta: "Ifigênia, obedecendo ao imperativo categórico da Crítica da razão prática, ainda não escrita então, renega seu próprio interesse, que precisava do engano, em nome da liberdade, da autonomia." (ADORNO, 1974, p. 509). Num gesto de confiança e sinceridade, Ifigênia explica a situação ao rei dos citas e consegue convencê-lo a permitir sua partida em companhia de Orestes. Segundo Adorno, que contesta a compreensão da peça como uma simples imitação do modelo clássico, os gregos e citas retratados por Goethe "pertencem a um estágio da humanidade historicamente determinado.” (ADORNO, 1974, p. 496). A Ifigênia alemã seria, assim, uma espécie de drama civilizatório, no qual os valores do humanismo moderno, iluminista, superam o poder de determinação da realidade pelas forças arcaicas do sacrifício e da violência mítica.

Esse comentário de Adorno define o teor do classicismo que marcou a obra de Goethe, uma retomada do mundo antigo na qual a questão da imitação dos gregos não só se insere numa discussão sobre os parâmetros para a criação artística moderna, como também ocorre segundo uma perspectiva romântica, carregada pela sensibilidade e pela moralidade do século XVIII. $\mathrm{O}$ autor da Ifigênia em Táuris tinha consciência disso, com base na avaliação feita por Schiller em cartas e depois no ensaio Poesia ingênua e sentimental, de 1795. Nas conversas registradas por Eckermann, Goethe declara, em março de 1830, que Schiller teria demonstrado naquele ensaio "que eu, contra a minha própria vontade, continuava a ser romântico, e que a minha Ifigênia, por causa do predomínio que nela tem o sentimento, não era de modo algum clássica, ao gosto antigo, como se poderia supor." (ECKERMANN, [19--?], p. 240).

Levando em conta as críticas incisivas, em textos de juventude ligados ao Sturm und Drang, ao teatro clássico francês e seu modelo de imitação dos antigos, o fato de Goethe ter decidido escrever uma Ifigênia é uma clara indicação de uma nova fase da sua carreira literária. Racine, por exemplo, um dos alvos daquelas críticas, tinha retomado o mito de Ifigênia numa peça de 1674. 
E, enquanto percorria a Itália, mergulhando na contemplaçáo das regiôes que visitava e descobrindo nelas uma nova conexão com o passado clássico, Goethe se empenhava em criar, como Racine fizera cem anos antes, uma nova Ifigênia.

Numa avaliação desse "livro singular" que é Viagem à Itália, no ensaio "Physiognomia, paisagem ideal e ficção autobiográfica", Selligman-Silva comenta que se trata de uma espécie de "diário de formação", mais do que de um relato de viagem, e que a visita de Goethe à Itália foi "a realização de sua formação por meio do périplo por um outro." (SELLIGMAN-SILVA, 2005, p. 269). Esse "outro", identificado com as paisagens e o clima do mediterrâneo, com o anseio pela claridade do Sul, não é exatamente o país do século XVIII visitado pelo escritor, mas sim o mundo antigo, tal como experimentado e estudado durante a viagem.

Ao retornar a Weimar, em 1788, depois de uma segunda estada em Roma, essa orientação para o classicismo definiria o rumo de toda uma fase da produção artística e das investigaçóes teóricas de Goethe. Com a colaboração de Schiller e de outros importantes intelectuais da época, ele formularia em Weimar, após seu retorno, uma teoria classicista da arte que se caracteriza pela relação com as ciências naturais. Nas obras literárias que retomam temas clássicos, a começar pela Ifigênia em Táuris, ele também procurou se aproximar do ideal clássico de uma relação harmoniosa com a natureza, mas sem copiar o modo de pensar dos antigos. "Engendrar uma Grécia por via racional" pode ser, nesse sentido, uma expressão do ideal do classicismo de Goethe, no qual a busca da máxima objetividade na observação e a profunda admiração pela Antiguidade se combinam, paradoxalmente, com os traços modernos de uma sensibilidade romântica e de um modo de pensar esclarecido. É essa combinação do passado e do presente, do clássico e do romântico, que permeia a formação relatada em Viagem à Itália.

SÜSSEKIND, P. Art and nature: on Goethe's travels in Italy. Trans/form/ação, Marília, v. 42, n. 3, p. 73-90, Jul./Set., 2019. 
ABSTRACT: The following paper discusses the book Italian Journey, in which J. W. Goethe described his travels in Italian territory in the years 1786 and 1787. I try to contextualize this journey within the writer's life and career, referring especially to a text by Walter Benjamin. I comment on Goethe's remarks on nature, which are linked to his scientific researches, but my main interest is in his remarks on art and classical antiquity. In these remarks, I recognize the important influence of the art historian J. J. Winckelmann and also a tendency toward classicism, something which defined Goethe's artistic production from the time of his Italian travels onward.

Keywords: Goethe. Winckelmann. Art. Nature. Classicism.

\section{REFERÊNCIAS}

ADORNO, T. Zum Klassizismus von Goethes Iphigenie. In: ADORNO, T. Noten zur Literatur IV. Gesammelte Schriften 11. Frankfurt: Suhrkamp, 1974.

BENJAMIN, W. Goethe. In: BENJAMIN, W. Ensaios reunidos: escritos sobre Goethe. São Paulo: Editora 34, 2009.

ECKERMANN, J. P. Conversações com Goethe. Lisboa: Vega, [19--?].

ELIAS, N. O processo civilizador. Rio de Janeiro: Zahar, 1993.

GOETHE, W. Winckelmann. In: GOETHE, W. Vermischte Schriften, Sechster Band. Frankfurt: Insel, 1965. . La métamorphose des plantes. Paris: Triades, 1975.

. Memórias: poesia e verdade. 2. ed. Brasília: Editora da Universidade de Brasília, 1986.

. Werke in sechs Banden. Frankfurt: Insel, 1993.

. Viagem à Itália. São Paulo: Companhia das Letras, 1999.

. Escritos sobre literatura. Rio de Janeiro: Editora 7letras, 2000.

GOETHE, W.; SCHILLER, F. Companheiros de viagem. Tradução de Claudia Cavalcanti. São Paulo: Nova Alexandria, 1993.

HAUSER, A. História social da arte e da literatura. São Paulo: Martins Fontes, 2000. p. 598-600.

HERDER, J. G. Shakespeare. In: Werke, Band I: Herder und der Sturm und Drang (1764-1774). Munique: Carl Hanser , 1984.

SELligMANN-SILVA, M. O local da diferença. São Paulo: Editora 34, 2005.

SÜSSEKIND, P. A recriação da Grécia: o debate de Goethe e Schiller sobre a imitação dos antigos. Kléos, n. 11/12, p. 77-89, 2007.

. A Grécia de Winckelmann. Kriterion, v. 49, n. 117, p. 67-77, 2008. 
SZONDI, P. Antike und moderne in der Ästhetik der Goethezeit. In: SZONDI, P. Poetik und Geschichtsphilosophie I. Studienausgabe der Vorlesungen Band 2. Frankfurt am Main: Suhrkamp, 1974.

WINCKELMANN, J. J. Réflexions sur l'imitation des oeuvres grecques en pinture et sculpture. Alerçon (Orne): Aubier, 1990 (Coleção bilíngue). 
SÜSSEKIND, P. 